(3) Two problems mentioned most frequently in the initial interviews were concerned with (a) the manager's lack of time to deal with all his duties properly, and $(b)$ the apparent impossibility of finding competent subordinates to whom could be delegated a field of responsibilities with complete confidence. It seemed that these two problems were closely related to one another, but that some managers would have been sorry if a solution had been found. Managers are short of time partly because they cannot find subordinates. Hence the manager becomes increasingly indispensable and has no timo to find and train subordinates. Hence he ceases seriously to ensure proper delegation. Hence the firm is dangerously dependent on his health, ability, adaptability and expectancy of working life.
(4) We formed a tentative hypothesis that a great deal of management problems were social in origin-coming from the society outside the firmand that possibly a great number of benefits also came from these external sources. We thought that these external sources of help might be the substitute in the small firm for benevolent head offices in the large organizations. We propose, therefore, to investigate the role of local government, local offices of ministries, trade associations, the banks, and consultants, in helping or hindering managers in their work.

(5) We propose to make comparative studies of management outside the business firm. A beginning has been made with a hospital, and it is hoped to invostigate the management problems of the professional practice, initially among architects.

\title{
THE UNDERGROUND LABORATORY OF THE NATIONAL CENTRE FOR SCIENTIFIC RESEARCH, FRANCE
}

$\mathrm{F}^{\mathrm{n}}$ RANCE is one of the countries which has made a considerable contribution to the development of spelæology and biospelæology. An underground laboratory with modern equipment was developed after the Second World War, through the efforts of Profs. Jeannel and Fage and with the financial assistance of the National Centre for Scientific Research. A decreo, dated Fobruary 11, 1948, specified that it should be built at Moulis, a small village in the Pyrenees, five kilometres west of Saint Girons. It took seven years to build, and was opened on June 26, 1954. The underground laboratory consists of a cave laboratory, which is equipped with low-voltage current and compressed air, and has a storage tank to collect the water of the underground stream running through it. The supply of water under pressure is ensured by a system of pumps and a hanging reservoir. The surface laboratory is some 300 yards from the cave, and includes laboratories, a library, bedrooms, a living room and a kitchen; the scientists are thus entirely independent. The original building has had an extra storey added to it and was considerably enlarged during 1960-61.

The laboratory was designed by zoologists and equipped for biological research. The cave laboratory is arranged so that cavernicolous animals can be raised there under optimum conditions, and investigations carried out in situ. It would be of great interest to carry out physical spelæology studies together with the biological investigations, as, for example, the study of the creation of underground cavities, the flow of underground streams and rivers, the composition of air and water in caves, underground meteorology, the creation and destruction of crystals and the composition of the clay found in the caves. A fuller knowledge of the physical media would, moreover, provide the biospelæologist with data of the highest value. For such work, however, specially equipped laboratories would have to be built and staffed with physicists and chemists. This will be a task for future generations.

Biospelæological research over the past fifteen years has dealt with three closely related problems: (1) the dovolopment and life-cycle of cavernicolous animals (worms, crustaceans, arachnids, insects, molluscs, fish and amphibians); (2) their meta- bolism; (3) their nutrition. The last-named has led to the birth of a new science, 'spelæobacteriology'.

One of the most serious gaps in biospelæological knowledge concerned the initial stages of cavernicolous life, about which little was known. Not only was survival of the animals made possible in the cave laboratory, but also almost all the species raised there also reproduced. The results obtained have been surprising and have justified the onterprise*.

Cavernicolous coleoptera can be divided into two main groups: Bathysciinae, which are omnivorous insects related to the Silphidae, and Trechinae, which are carnivorous insects related to the Carabaeid family. The way in which they have developed was unknown until recently. This problem has been resolved in the course of the past ten years by Mme. Glaçon-Deleurance's observations. There are several types of development of cavernicolous Bathysciinae, the degree of specialization of which is correlative to the 'cavernicolarity' of the insect. The peculiar cycle of the most cavernicolous of the Bathysciinae, such as Speonomus longicornus, was at first thought to be a deviation due to captivity. The initial results were soon confirmed, however, and there is now no doubt that the cycle observed in the laboratory is the same as that occurring under normal conditions.

In the most specialized species of Bathysciinae, the female lays only one egg at a time; this egg is extremely large and completely filled with vitellus. It hatches into a larva which has a short larval stage, (from a fow hours to a fow days). This explains why such larvæ had never been found in the caves, and were unknown until Mme. Glaçon-Deleurance carried out her observations. The larva rapidly builds itself a clay case in which it pupates. In the course of its brief larval life, the insect does not feed, grow or moult; it therefore has only one larval stage, whereas coleoptera normally moult twice and thus have three stages. The peculiar growth-cycle of this highly specialized species is related to the normal cycle by a series of intermediate species. Mme. Glaçon-Deleurance also resolved the problem of the development of Trechinae and, particularly, of

* French Science News, No. I, January-March, 1962. (Paris: Mintstère des Affaires Etrangeres-Direction Générale des Affaires
Culturelles et Techniques, 1962.) 
Aphaenops, which is the most remarkable cavernicolous animal of the Pyrenean caves.

The comparative physiology of cavernicolous creatures and their epigeous counterparts was studied by Mme. Derouet-Dresco, who had worked with Prof. Fontaine. She has carried out research work on both aquatic crustaceans and spiders. In a remarkable thesis presented last year, M. R. Ginet mentioned that the growth of Niphargus is much slower than that of Gammarus, but that its life-span is far longer. After a comparison between the respiration-rates of epigeous spiders and the cavernicolous species, Mme. Derouet-Dresco showed that metabolism of the cavernicolous animals is less active than that of their closest biological relatives above ground, and can be compared with the metabolism of an ageing creature. This explains their extremely slow development and also their long life.

Biospelæologists have long suspected that the clay in the caves played an important part in the life of cavernicolous animals, either in their nutrition or in their reproduction and development. Research on the nutritional implication started when Rene Ginet carried out breeding tests with Niphargus in 1956. He showed that the young Niphargus continues to develop, for a certain length of time, in tanks containing clay but with no actual food of any sort, whereas when given food but no elay, all the young Niphargus die during their second moult. A research programme was therefore drawn up to investigate the properties of the clays.

Victor Caumartin, the co-ordinator of the research team, used an electronic microscope to discover a wide variety of bacterial flora in this underground clay, as well as certain types of porous rock, such as dolomite. One of his discovories was a hitherto unknown ferrobacterium to which he gave the name of Perabacterium spelai. This bacterium is anærobic in its natural medium, and is completely autotrophic.
It fixes the nitrogen of the air and gets its carbon from 'ferric carbonate'. The energy necessary for its metabolism is supplied by the decomposition of ferric carbonate, which frees ferrous oxide, and this in turn is transformed by oxidation into ferric oxide. When the supply of ferrous salts in the clay is exhausted the bacteria disappear and the clay becomes a strictly inorganic substance.

This remarkable bacterial species is the only one which has been studied in any detail, and its discovery sheds a new light on the clay found in these underground cavities. It is not only an inorganic mixture, but also a living medium which produces organic substances and can serve as food for cavernicolous creatures. The bacteria, and also the fungi, can synthesize the vitamins and growth substances which are normally supplied to animals by grass. This discovery shows the possible existence of a purely endogenous cycle within the depths of the Earth, to which no exogenous contribution is made. The closed cycle could be similar to that observed in the great marine trenches. Ginet and Miss Gounot give an initial, although tentative, insight into the interdependent nutrition cycles of the subterranean world.

The basic eycle is dependent on autotrophic bacteria and on ferro-bacteria in particular. A second, as yet incompletely known cycle is probably dependent on heterotrophic and saprophytic bacteria, and on various protista, amœbæ and flagellate zoospores. Limivora, such as Nematoda and Oligochæta, feed on this 'living clay' as do young Niphargus and Proteus. The Carnivora (adult Niphargus and Planaria) feed on Limivora. Finally, Proteus, which can be considered as a supercarnivore, feeds on Niphargus and Troglocaris. These cycles have as yet been observed only with aquatic animals, but it is probable that similar nutrition cycles govern the life of terrestrial cavernicolous animals.

\section{THE BRITISH GELATINE AND GLUE RESEARCH ASSOCIATION}

\begin{abstract}
THE twenty-second meeting of the Research Panel of the British Gelatine and Glue Research Association was held on November 8, 1961, with the director of research, Dr. D. A. Sutton, in the chair.

Dr. F. S. Steven (University of St. Andrews) presented the first paper on his work with Dr. G. R. Tristram, entitled "The Presence of Non-ProteinNitrogen associated with Soluble Calf Skin Collagen". It has been found that soluble collagen extracted by the acetic acid method and precipitated by sodium chloride contains a significant amount of non-protein nitrogen even after five successive dissolutions and precipitations. This 2 per cent of nonprotein nitrogen material is left in solution when the collagen is adjusted to $p \mathrm{H} 1 \mathrm{l}$ and acetone is added, or it can be obtained by other procedures such as a combination of dialysis at $p \mathrm{H} 3.5$ and acetone precipitation of the dialysate. It cannot be dialysed from the (precipitated) collagen at $p \mathrm{H} 7$ nor does the addition of acetone free it at this $p H$. It would appear, therefore, that the non-protein nitrogen material is physically bound to the protein and it was shown by paper ehromatography to contain eleven ninhydrin-positive components of which nine were amino-acids. Similar experiments were carried out with alkali-processed gelatines. The
\end{abstract}

discussion centred round the possible bearing of these findings on the Courts and Stainsby multi-chain model for gelatin, since a relatively small percentage of amino-acids would cause a disproportionate drop in the found average chain weight as compared with the weight average molecular weight. Dr. Sutton pointed out that the authors' results were consistent with the supposition that only about 1 per cent of the non-protein-nitrogen material was amino-acid so that the bulk of it was presumably peptides, which would have a smaller effect on the ratio of chain weight to molecular weight.

The second paper, by Mr. N. T. Crosby and Dr. G. Stainsby (University of Leeds), "The Stability of Solutions of Solubilized Collagens", reviewed relationships between collagens extracted from skin in the cold by acid buffers and the soluble eucollagens which become extractable after skin has been soaked in cold alkali. The differences between the two groups are mainly quantitative, for example, soluble eucollagen preparations lie within a wider intrinsic viscosity-range and have slightly lower denaturation temperatures. Certain qualitative differences do exist, however, such as the absence of the $640 \AA$ periodicity in reconstituted eucollagen fibrils and their lowered isoionic point arising from the loss of 